\title{
Analisis Estimasi Biaya Langsung Medis Penderita Rawat Jalan Diabetes Mellitus Tipe 2 di RSUD Dr. Abdul Aziz Singkawang Tahun 2013
}

\author{
Mursalin', Prastuti Soewondo ${ }^{2}$ \\ ${ }^{1}$ Fakultas Kesehatan Masyarakat Universitas Indonesia, \\ ²Departemen Administrasi Kebijakan Kesehatan, Fakultas Kesehatan Masyarakat Universitas Indonesia \\ Contact: mursal1976@yahoo.co.id \\ Reviewed October 20, 2016, and accepted on November 5, 2016
}

\begin{abstract}
Abstrak
Diabetes Mellitus merupakan penyakit epidemik yang menjadi ancaman global. Selain tingkat morbiditas dan mortalitas yang tinggi, juga menyebabkan sebagian besar negara di dunia mengeluarkan anggaran kesehatan yang besar. Penelitian ini bertujuan untuk menghitung besarnya biaya langsung medis dan faktor-faktor yang mempengaruhinya pada penderita rawat jalan diabetes mellitus tipe 2. Penelitian dilaksanakan pada bulan Januari - Februari 2015 di RSUD dr. Abdul Aziz Singkawang, Kalimantan Barat. Jenis penelitian ini adalah kuantitatif analitik dengan menggunakan data sekunder yang dikumpulkan secara retrospektif berdasarkan data tahun 2013 dengan jumlah sampel sebanyak 200. Hasil analisis multivariat, terdapat perbedaan yang signifikan biaya langsung medis pada setiap tipe penatalaksanaan, lama sakit dan komplikasi yang dialami penderita. Upaya promotif dan preventif perlu ditingkatkan untuk mencapai efektivitas dan efisiensi pengobatan dan meningkatkan kualitas hidup penderita.
\end{abstract}

Kata kunci : biaya langsung medis, penderita rawat jalan diabetes mellitus tipe 2, faktor - faktor yang mempengaruhi

\begin{abstract}
Diabetes mellitus has epidemic diseases that seriously global threated. Except, hight level of morbidity and mortality, its also caused most countries in the world spend a lot of money for health care. This study purpose to count direct medical costs and factors of influence on type 2 diabetes mellitus outpatient care. This study conduct on January to February 2015 in RSUD dr. Abdul Aziz Singkawang at West Kalimantan. Design study used cuantitative analysis by secondary data that retrospectively collected on 2013 data and number of samples are 200. Result of multivariate analysis, there were significant difference means of direct medical costs of type 2 diabetes mellitus outpatient care on type of care, diseases duration, and complication. Health promotion and prevention on type 2 diabetes mellitus intervention must be increasingly to achieve effective and efficient cost of care and to increase patient's quality of life.
\end{abstract}

Key words : direct medical costs, type 2 diabetes mellitus outpatient care, associated factors, health promotion and prevention.

\section{Pendahuluan}

Diabetes Mellitus adalah suatu kumpulan gejala yang timbul pada seseorang yang disebabkan oleh peningkatan kadar glukosa darah akibat penurunan sekresi insulin yang progresif dilatarbelakangi oleh resistensi insulin (Soegondo et al, 2009). Diabetes mellitus atau penyakit kencing manis, kini menjadi perhatian serius. Keseriusan ini lantaran Sidang Umum Persatuan Bangsa Bangsa (PBB) dalam press release tanggal 20 Desember 2006 telah mengeluarkan Resolusi Nomor 61/225 yang mendeklarasikan bahwa epidemik diabetes mellitus merupakan ancaman global dan serius sebagai salah satu penyakit tidak menular yang menitikberatkan pada pencegahan dan pelayanan diabetes di seluruh dunia. Sidang ini juga menetapkan tanggal 14 Nopember sebagai Hari Diabetes Se-Dunia (World Diabetes Day) yang dimulai tahun 2007.

Data dari studi global International Diabetes Federation (IDF, 2011) menunjukkan bahwa jumlah penderita diabetes mellitus pada tahun 2011 telah mencapai 366 juta orang. Jika tidak ada tindakan yang dilakukan, jumlah ini diperkirakan akan meningkat menjadi 552 juta pada tahun 2030. Diabetes mellitus telah menjadi penyebab dari 4,6 juta kematian.

Di Indonesia sendiri, berdasarkan hasil Riset Kesehatan Dasar (Riskesdas) tahun 2013, penderita diabetes mellitus yang terdiagnosis dokter mencapai 1,5 persen dari jumlah penduduk Indonesia dan yang terdiagnosis dokter atau mengalami gejala sebesar 2,1 persen.

Diabetes mellitus adalah penyakit yang tidak bisa sembuh total, bahkan butuh perawatan lama yang mahal, menghabiskan biaya tak sedikit. Apalagi sampai komplikasi seperti penyakit jantung, stroke, dan komplikasi lainnya sehingga besaran biaya yang harus dikeluarkan bertambah beberapa kali lipat. WHO memperkirakan kebanyakan negara di seluruh dunia mengeluarkan 2,5 - 15 persen anggaran kesehatannya untuk diabetes mellitus (Harnowo PA, 2012).

Menurut IDF tahun 2011 pengeluaran biaya keseha- 
tan untuk diabetes mellitus telah mencapai 465 miliar USD. Biaya itu, terdiri perawatan langsung untuk diabetes US\$116 miliar atau 67 persen dari total biaya. Juga, biaya tak langsung sebesar US\$58 miliar atau 33 persen.

Menurut Rascati dalam Essentials of farmacoeconomics (2009) biaya langsung terdiri dari 2 tipe yaitu biaya langsung medis (direct medical cost) dan biaya langsung non medis (direct nonmedical cost). Biaya langsung medis (direct medical cost) terdiri dari biaya obat, konseling dan konsultasi pasien, tes diagnosa, biaya rawat inap, rawat jalan, gawat darurat, pengobatan dan perawatan di rumah, pelayanan ambulans dan pelayanan keperawatan. Sedangkan biaya langsung non medis (direct nonmedical cost) terdiri dari biaya perjalanan untuk mendapatkan pelayanan kesehatan, biaya makan pada keluarga yang menemani pasien, penginapan untuk pasien dan keluarga untuk pengobatan di luar kota, dan pelayanan kesehatan anak untuk anak pasien.

Penelitian ROSSO (Retrospective Study Self-Monitoring of Blood Glucose and Outcome in People with type 2 Diabetes) di Jerman tahun 2006 oleh Weber et al, diketahui pengeluaran biaya diabetes mellitus oleh pasien, besarannya semakin meningkat dari tahun ke tahun, seiring dengan laju komplikasi yang dialami. Tahun pertama setelah didiagnosis, pasien diabetes mengeluarkan biaya sebesar 18,3 juta rupiah setahun, hingga menjadi 49,1 juta rupiah pada tahun ke delapan.

Di Indonesia, beban biaya yang dikeluarkan untuk diabetes mellitus setiap tahunnya sekitar 5 triliun rupiah sampai 8 triliun rupiah. Perkiraan biaya yang timbul setiap tahun tersebut baru meliputi biaya langsung. Belum memperhitungkan biaya tidak langsung akibat diabetes mellitus seperti kehilangan kesempatan belajar dan bekerja (Thabrany H, 2013 dalam Widiyani R, 2013).

Pada 2012 total biaya rawat jalan yang ditanggung PT. ASKES adalah Rp. 253.347.351.569,- untuk pengobatan, dan Rp. 103.113.249.659,- untuk selain pengobatan. Sementara untuk rawat inap biaya yang dikeluarkan adalah Rp. 40.192.886.042,- untuk pengobatan dan Rp. 114.705.057.013,- untuk selain pengobatan (Widiyani R, 2013).

Penelitian tentang biaya langsung medis pada pasien diabetes mellitus tipe 2 dilakukan di Swedia oleh Henriksson F., et al dari Pusat Ekonomi Kesehatan Sekolah Ekonomi Stockholm yang dipublikasikan pada jurnal of International Medicine tahun 2000 yang berjudul "Direct Medical Costs for Patients With Type 2 Diabetes in Sweden”. Terdapat tiga penyebab adanya perbedaan biaya langsung medis pada pasien diabetes mellitus tipe 2, yaitu tipe penatalaksanaan, lama menderita sakit dan adanya komp- likasi yang diderita pasien.

Penelitian lain dilakukan oleh Koster I., et al yang berjudul "The Cost Burden of Diabetes Mellitus: The Evidence from Germany-The CoDiM Study”. Penelitian ini menggunakan multipel regresi yang memperlihatkan bahwa variabel jenis kelamin, umur dan tipe pengobatan mencatat 21,2 persen variasi biaya langsung (direct cost). Seluruh variabel tadi memiliki tingkat signifikansi yang tinggi $(\mathrm{p}<0,001)$.

Penelitian lain oleh Wang W, et al yang dipublikasikan tahun 2010 dengan judul "Factor affecting costs and utilization of type 2 diabetes healthcare: a cross-sectional survey among 15 hospitals in urban China", menyatakan faktor terapi insulin, adanya komplikasi dan lama sakit signifikan mempengaruhi rata-rata biaya langsung medis pasien diabetes mellitus tipe 2 pertahun dengan nilai $\mathrm{p}<0,01$ dan faktor terapi obat dan jenis kelamin dengan nilai $\mathrm{p}<0,05$. Rata-rata biaya langsung medis laki-laki sebesar 8.410 CNY dan perempuan 7.581 CNY.

Untuk mencapai kualitas hidup yang optimal dengan biaya pelayanan kesehatan yang efektif dan efisien pada penderita diabetes mellitus, upaya pencegahan komplikasi dilakukan oleh BPJS (Badan Penyelenggara Jaminan Sosial) Kesehatan melalui Program Pengelolaan Penyakit Kronis (Prolanis) yang bekerja sama dengan antara lain PB-PERKENI dan IDI. Prolanis memungkinkan penderita diabetes mellitus terdaftar di puskesmas dan dokter layanan primer terdekat. Pasien juga bisa mengikuti edukasi untuk meningkatkan kualitas hidup dan mencegah komplikasi.

Oleh sebab itu, karena dampak ekonominya sangat luar biasa dan biaya langsung medis yang ditanggung penderita, keluarga maupun negara begitu besar, terutama yang mengalami komplikasi, maka estimasi perhitungan besarnya biaya langsung medis penderita rawat jalan diabetes mellitus tipe 2 perlu untuk dilakukan.

\section{Metodologi Penelitian \\ Metode}

Jenis penelitian ini adalah kuantitatif analitik, dengan menggunakan data sekunder yang dikumpulkan secara retrospektif study berdasarkan data tahun 2013.

\section{Lokasi dan Waktu Penelitian}

Pengumpulan data untuk penelitian ini dilakukan di RSUD dr. Abdul Aziz Singkawang Kalimantan Barat yang merupakan Rumah Sakit Tipe B pada bulan Januari - Pebruari 2015.

\section{Populasi dan Sampel}

Populasi target penelitian ini adalah adalah seluruh penderita rawat jalan diabetes mellitus tipe 2 yang berobat di 
RSUD Dr. Abdul Aziz Singkawang dalam kurun waktu Januari - Desember 2013.

Sampel penelitian ini adalah seluruh populasi target dengan kriteria sebagai berikut :

a. Kriteria Inklusi

- Penderita diabetes mellitus tipe 2 .

- Penderita yang berobat rawat jalan di RSUD dr. Abdul Aziz Singkawang.

- Penderita yang rutin mengikuti pengobatan dalam kurun waktu Januari - Desember 2013.

- Penderita dengan catatan medis yang lengkap.

Jumlah sampel minimal untuk data numerik diperoleh dengan menggunakan rumus perhitungan besar sampel estimasi rata-rata pada sampel acak sederhana dengan presisi relatif (Ariawan, 1998).

Berdasarkan rumus tersebut, diperoleh bahwa jumlah sampel yang dibutuhkan dalam penelitian ini adalah sebesar 200 penderita.

\section{Pengumpulan Data}

Tehnik pengumpulan data dilakukan menggunakan data sekunder berupa rekam medis pasien (medical record) untuk data variabel independen yaitu: jenis kelamin, umur, tipe penatalaksanaan, lama sakit, komplikasi yang dialami dan data peserta Prolanis di BPJS Kesehatan untuk keikutsertaan dalam Prolanis. Sedangkan data biaya langsung medis (direct medical cost) atau variabel dependen dilakukan perhitungan biaya dengan menggunakan metode $A c-$ tivity Based Costing ( $\mathrm{ABC})$.

\section{Hasil Penelitian}

\section{Analisis Univariat}

Analisis deskkripsi dilakukan untuk menjelaskan karakteristik masing-masing variabel baik variabel dependen maupun independen. Tabel 1 memperlihatkan deskripsi masing-masing variabel yang diteliti. Pada jenis kelamin penderita, sebanyak 96 penderita $(48,0 \%)$ adalah laki-laki dan 104 (52,0\%) adalah perempuan. Umur penderita, sampel terbanyak adalah penderita berumur $40 \mathrm{~s} / \mathrm{d} 59$ Tahun yaitu 127 (63,5\%), lalu diikuti oleh penderita berumur $\geq 60$ Tahun sebanyak 69 (34,5\%) dan terakhir $<40$ tahun hanya 4 penderita $(2,0 \%)$. Sedangkan tipe penatalaksanaan pada penderita, hanya 15 penderita $(7,5 \%)$ yang mendapat terapi insulin saja dan kombinasi dengan $\mathrm{OHO}$, sedangkan penderita yang menggunakan obat berkhasiat hipoglikemik (OHO) sebanyak 185 (92,5\%).

Rata-rata lama sakit penderita yang menjadi sampel penelitian ini adalah 6 tahun dengan standar deviasi 3,5 tahun dan yang paling singkat adalah 1 tahun dan paling lama menderita diabetes mellitus 23 tahun. Karena variabel ini numerik, maka dilakukan uji normalitas data. Hasilnya variabel lama sakit berdistribusi tidak normal, dimana pada uji one sample kolmogorov-smirnov test nilai $\mathrm{p}=0,002<0,05$.

Komplikasi yang terbanyak dialami penderita adalah komplikasi makrovaskuler sebanyak 91 penderita $(45,5 \%)$, diikuti komplikasi keduanya (makro dan mikro vaskuler) 52 (26,0\%), lalu tidak mengalami komplika-

Tabel 1. Analisis Univariat

\begin{tabular}{|c|c|c|c|}
\hline Variabel & \multicolumn{3}{|r|}{ Persentase (\%) } \\
\hline \multicolumn{4}{|l|}{ a. Independen } \\
\hline $\begin{array}{l}\text { - Jenis Kelamin } \\
\text { 1. Laki-laki } \\
\text { 2. Perempuan }\end{array}$ & \multicolumn{3}{|r|}{$\begin{array}{l}48,0 \\
52,0\end{array}$} \\
\hline $\begin{array}{l}\text { - Umur } \\
\text { 1. }<40 \text { Tahun } \\
\text { 2. } 40 \mathrm{~s} / \mathrm{d} 59 \text { Tahun } \\
\text { 3. } \geq 60 \text { Tahun }\end{array}$ & \multicolumn{3}{|r|}{$\begin{array}{l}2,0 \\
63,5 \\
34,5\end{array}$} \\
\hline $\begin{array}{l}\text { - Tipe Penatalaksanaan } \\
\text { 1. Menggunakan obat berkhasiat hipoglikemik (OHO) } \\
\text { 2. Insulin saja dan kombinasi dengan } \mathrm{OHO}\end{array}$ & \multicolumn{3}{|r|}{$\begin{array}{c}92,5 \\
7,5 \\
\end{array}$} \\
\hline & Mean & $\mathrm{SD}$ & Min-Maks \\
\hline \multirow[t]{2}{*}{ - Lama Sakit (Tahun) } & 6,29 & 3,468 & $1 \mathrm{~s} / \mathrm{d} 23$ \\
\hline & \multicolumn{3}{|r|}{ Persentase (\%) } \\
\hline $\begin{array}{l}\text { - Komplikasi yang dialami } \\
\text { 1. Tidak mengalami komplikasi } \\
\text { 2. Komplikasi mikrovaskuler } \\
\text { 3. Komplikasi makrovaskuler } \\
\text { 4. Komplikasi keduanya }\end{array}$ & & . & $\begin{array}{l}18,0 \\
10,5 \\
45,5 \\
26,0\end{array}$ \\
\hline $\begin{array}{l}\text { - Keikutsertaan dalam Prolanis } \\
\text { 1. Mengikuti Prolanis } \\
\text { 2. Tidak mengikuti Prolanis }\end{array}$ & \multicolumn{3}{|r|}{$\begin{array}{l}37,0 \\
63,0\end{array}$} \\
\hline b. Dependen & Mean (Rp) & $\mathrm{SD}(\mathrm{Rp})$ & Min-Maks (Rp) \\
\hline Biaya Langsung Medis & 2.406 .325 & 1.634 .505 & $171.644 \mathrm{~s} / \mathrm{d} 9.626 .682$ \\
\hline
\end{tabular}


si $36(18,0 \%)$ dan komplikasi mikrovaskuler hanya 21 $(10,5 \%)$. Jadi total penderita yang mengalami komplikasi sebanyak 164 penderita $(82,0 \%)$. Jenis penyakit komplikasi terbanyak yang dialami penderita berturut-turut adalah hipertensi yang dialami oleh 141 penderita, neuropati pada 51 penderita, nefropati pada 26 penderita, gagal jantung kongestif pada 17 penderita, retinopati pada 11 penderita, penyakit jantung koroner pada 10 penderita dan penyakit jantung iskemik serta stroke masing-masing 2 penderita. Sedangkan keikutsertaan penderita dalam Prolanis, hanya 74 penderita $(37,0 \%)$ yang aktif mengikuti Prolanis sedangkan selebihnya yaitu 126 (63,0\%) tidak mengikuti Prolanis.

Rata-rata biaya langsung medis untuk setiap penderita rawat jalan diabetes mellitus tipe 2 di RSUD dr. Abdul Aziz Singkawang dalam setahun sebesar Rp. 2,406,325 dengan standar deviasi sebesar Rp. 1,634,505 dan biaya terendah sebesar Rp. 171,644 dan tertinggi sebesar Rp. 9,626,682. Pada CI 95\% biaya langsung medis sebesar Rp. 2,178,413 sampai dengan Rp. 2,634,238.

Biaya terbesar adalah untuk obat-obatan yang mencapai $75,65 \%$ dari total biaya dengan rata-rata untuk setiap penderita sebesar Rp. 1,820,502 dengan biaya terendah sebesar Rp. 31,060 dan tertinggi sebesar Rp. 9,418,850. Sedangkan biaya untuk obat-obatan diabetes mellitus berupa terapi OHO dan insulin sebesar 47,32\% dari total biaya dan rata-rata sebesar Rp. 1,138,567 dengan biaya terendah Rp. 6,600 dan tertinggi Rp. 7,130,000. Selain itu, biaya obat-obatan untuk mengatasi komplikasi dan komorditas sebesar 28,34\% dari total biaya dengan rata-rata untuk setiap penderita sebesar Rp. 681,935 dengan biaya terendah tidak ada dan tertinggi Rp. 6,123,770. Biaya selain obat-obatan sebesar $24,35 \%$ dari total biaya yang terdiri dari biaya pemeriksaan laboratorium sebesar 9,14\%, selanjutnya berturut-turut biaya Poliklinik Penyakit Dalam 7,83\%, Apotek 3,76\% dan biaya Pendaftaran 1,98\%. Sedangkan biaya Pemeriksaan EKG, Poliklinik Bedah, Poliklinik Mata, Poliklinik Syaraf dan Poliklinik Fisioterapi kurang dari 1\% dari total biaya.

Variabel dependen yaitu biaya langsung medis adalah numerik, maka dilakukan uji normalitas data. Hasilnya variabel biaya langsung medis berdistribusi normal, dimana pada uji one sample kolmogorov-smirnov test nilai $\mathrm{p}=$ 0,09 (>0,05).

\section{Analisis Bivariat}

Perbedaan rata-rata biaya langsung medis untuk penderita rawat jalan diabetes mellitus tipe 2 dalam setahun pada penderita laki-laki dan perempuan.

Rata-rata biaya langsung medis untuk penderita rawat jalan diabetes mellitus tipe 2 dalam setahun pada penderi- ta laki-laki sebesar Rp. 2.418.957,- lebih tinggi dibandingkan dengan penderita perempuan yaitu Rp. 2.394.665,-

Tabel 2. Biaya Langsung Medis Penderita Rawat Jalan Diabetes Mellitus Tipe 2 di RSUD Dr. Abdul Aziz Singkawang Tahun 2013 Menurut Jenis Kelamin

\begin{tabular}{lrcccc}
\hline Jenis kelamin & Mean $(\mathbf{R p})$ & SD $(\mathbf{R p})$ & SE $(\mathbf{R p})$ & N & P-value \\
\hline Laki- laki & 2.418 .957 & 1.525 .205 & 155.666 & 96 & 0,917 \\
\hline Perempuan & 2.394 .665 & 1.736 .603 & 170.288 & 104 & \\
\hline
\end{tabular}

Namun, hasil uji statistik didapatkan nilai $\mathrm{p}=0,917$, berarti tidak ada perbedaan yang signifikan rata-rata biaya langsung medis antara penderita laki-laki dan perempuan. Perbedaan rata-rata biaya langsung medis untuk penderita rawat jalan diabetes mellitus tipe 2 dalam setahun pada setiap kelompok umur penderita.

Tabel 3. Biaya Langsung Medis Penderita Rawat Jalan Diabetes Melllitus Tipe 2 di RSUD dr. Abdul Aziz Singkawang Tahun 2013 menurut Kelompok Umur

\begin{tabular}{lccccr}
\hline Kelompok Umur & Mean (Rp) & SD (Rp) & 95\% CI (Rp) & N & P-value \\
\hline < 40 Tahun & 1.349 .126 & 722.698 & $199.152-2.499 .101$ & 4 & \\
\cline { 1 - 5 } 40 s/d 59 Tahun & 2.307 .156 & 1.591 .143 & $2.027 .743-2.586 .569$ & 127 & \multirow{2}{*}{0,159} \\
\cline { 1 - 4 }$\geq 060$ Tahun & 2.650 .142 & 1.720 .390 & $2.236 .859-3.063 .425$ & 69 & \\
\hline
\end{tabular}

Rata-rata biaya langsung medis untuk penderita rawat jalan diabetes mellitus tipe 2 dalam setahun pada penderita berumur < 40 tahun sebesar Rp. 1.349.126,- Biaya meningkat pada penderita berumur $40 \mathrm{~s} / \mathrm{d} 59$ tahun yaitu sebesar Rp. 2.307.156,- dan kembali meningkat pada penderita berumur $\geq 60$ tahun yaitu Rp. 2.650142,Hasil uji statistik didapatkan nilai $p=0,159$, berarti tidak ada perbedaan yang signifikan rata-rata biaya langsung medis pada kelompok umur penderita.

Perbedaan rata-rata biaya langsung medis untuk penderita rawat jalan diabetes mellitus tipe 2 dalam setahun pada setiap tipe penatalaksanaan.

Tabel 4. Biaya Langsung Medis Penderita Rawat Jalan Diabetes Melllitus Tipe 2 di RSUD dr. Abdul Aziz Singkawang Tahun 2013 menurut Tipe Penatalaksanaan

\begin{tabular}{lccccc}
\hline \multicolumn{1}{c}{ Tipe penatalaksanaan } & Mean (Rp) & SD (Rp) & SE (Rp) & N & P-value \\
\hline $\begin{array}{l}\text { Menggunakan Obat berkhasiat } \\
\text { hipoglikemik (OHO) }\end{array}$ & 2.258 .422 & 1.447 .181 & 106.399 & 185 & \\
\cline { 1 - 4 } $\begin{array}{l}\text { Insulin saja dan kombinasi } \\
\text { dengan OHO }\end{array}$ & 4.230 .465 & 2.568 .122 & 663.086 & 15 & 0,010 \\
\hline
\end{tabular}

Rata-rata biaya langsung medis untuk penderita rawat jalan diabetes mellitus tipe 2 dalam setahun pada penderita yang menggunakan obat berkhasiat hipoglikemik (OHO) sebesar Rp. 2.258.422,- dan jauh lebih rendah dibandingkan dengan penderita dengan terapi insulin saja dan kombinasi dengan OHO yaitu Rp. 4.230.465,- Hasil uji statistik didapatkan nilai $\mathrm{p}=0,010$, berarti ada perbedaan yang signifikan rata-rata biaya langsung medis pada 
kedua tipe penatalaksanaan.

Perbedaan rata-rata biaya langsung medis untuk penderita rawat jalan diabetes mellitus tipe 2 dalam setahun pada setiap penambahan satu tahun lama menderita sakit.

Variabel lama sakit memiliki data berdistribusi tidak normal, maka sebelum dilakukan analisis bivariat, data tersebut harus ditransformasi terlebih dahulu kedalam bentuk logaritma dengan menggunakan Ln.

Tabel 5 Biaya Langsung Medis Penderita Rawat Jalan Diabetes Melllitus Tipe 2 di RSUD dr. Abdul Aziz Singkawang Tahun 2013 menurut Lama Sakit

\begin{tabular}{ccccc}
\hline Variabel & $\mathbf{r}$ & $\mathbf{R}^{2}$ & Persamaan Garis (Rp) & P-value \\
\hline Lama Sakit & 0,174 & 0,030 & $1.646 .707+455.170$ & 0,014 \\
\hline
\end{tabular}

Hasil uji statistik didapatkan nilai $\mathrm{p}=0,014$ pada korelasi pearson maupun regresi linier. Dengan demikian, dapat dikatakan bahwa terdapat perbedaan yang signifikan rata-rata biaya langsung medis dengan lama sakit. Selain itu didapatkan persamaan regresi, yaitu: Biaya langsung medis $=1.646 .707+455.170$ (log lama sakit). Karena merupakan model persamaan relatif (model lin$\log$ ), maka dapat diartikan bahwa setiap penambahan $1 \%$ tahun lama sakit, biaya langsung medis akan bertambah (Rp. 455.170,- * 0,01) = Rp. 4.551,70 atau sama dengan setiap penambahan 1 tahun lama sakit biaya langsung medis akan bertambah Rp. 455.170.

Perbedaan rata-rata biaya langsung medis untuk penderita rawat jalan diabetes mellitus tipe 2 dalam setahun pada setiap jenis komplikasi yang dialami

Tabel 6. Biaya Langsung Medis Penderita Rawat Jalan Diabetes Melllitus Tipe 2 di RSUD dr. Abdul Aziz Singkawang Tahun 2013 menurut Jenis Komplikasi

\begin{tabular}{lccccc}
\hline \multicolumn{1}{c}{ Jenis komplikasi } & Mean (Rp) & SD (Rp) & 95\% CI (Rp) & N & P-value \\
\hline $\begin{array}{l}\text { Tidak mengalami } \\
\text { komplikasi }\end{array}$ & 1.430 .864 & 1.049 .574 & $1.075 .739-1.785 .989$ & 4 & \\
\cline { 1 - 4 } $\begin{array}{l}\text { Komplikasi mikro- } \\
\text { vaskuler }\end{array}$ & 1.849 .720 & 1.011 .679 & $1.389 .210-2.310 .231$ & 127 & \\
\cline { 1 - 4 } $\begin{array}{l}\text { Komplikasi makro- } \\
\text { vaskuler }\end{array}$ & 2.411 .945 & 1.660 .067 & $2.066 .219-2.757 .670$ & 69 & \\
\cline { 1 - 3 } $\begin{array}{l}\text { Komplikasi } \\
\text { keduanya }\end{array}$ & 3.296 .594 & 1.672 .277 & $2.831 .029-3.762 .159$ & & \\
\hline
\end{tabular}

Rata-rata biaya langsung medis untuk penderita rawat jalan diabetes mellitus tipe 2 dalam setahun meningkat seiring komplikasi yang dialami. Pada penderita yang tidak mengalami komplikasi biaya sebesar Rp. 1,430,864, biaya meningkat menjadi sebesar Rp. 1,849,720 pada penderita dengan komplikasi mikrovaskuler, lalu meningkat kembali menjadi Rp. 2,411,945 pada penderita dengan komplikasi makrovaskuler. Selanjutnya kembali meningkat pada penderita yang mengalami komplikasi keduanya menjadi Rp. 3,296,594. Hasil uji statistik didapatkan nilai $\mathrm{p}=0,0005$, berarti terdapat perbedaan yang signifikan rata-rata biaya langsung medis pada setiap jenis komplikasi yang dialami.

Perbedaan rata-rata biaya langsung medis untuk penderita rawat jalan diabetes mellitus tipe 2 dalam setahun pada setiap jenis komplikasi yang dialami

Rata-rata biaya langsung medis untuk penderita rawat jalan diabetes mellitus tipe 2 dalam setahun pada penderita yang mengikuti Prolanis sebesar Rp. 2.465.706,- lebih tinggi dibandingkan dengan penderita yang tidak mengikuti Prolanis yaitu Rp. 2.371.451,-

Tabel 7. Biaya Langsung Medis Penderita Rawat Jalan Diabetes Melllitus Tipe 2 di RSUD dr. Abdul Aziz Singkawang Tahun 2013 menurut Keikutsertaan dalam Prolanis

\begin{tabular}{lccccc}
\hline Keikutsertaan dalam Prolanis & Mean $(\mathrm{Rp})$ & SD $(\mathrm{Rp})$ & SE $(\mathrm{Rp})$ & N & P-value \\
\hline Mengikuti Prolanis & 2.465 .706 & 1.793 .581 & 208.499 & 74 & \multirow{2}{*}{0,0005} \\
\cline { 1 - 5 } Tidak mengikuti Prolanis & 2.371 .451 & 1.539 .869 & 137.182 & 126 & \\
\hline
\end{tabular}

Hasil uji statistik didapatkan nilai $\mathrm{p}=0,695$, berarti tidak ada perbedaan yang signifikan rata-rata biaya langsung medis antara yang mengikuti dan tidak mengikuti Prolanis.

\section{Analisis Bivariat}

Setelah tahap bivariat selesai, maka tahap berikutnya melakukan analisis multivariat secara bersama-sama. Prinsip pemodelan harus sederhana. Semua variabel perlu dicek nilai $\mathrm{p}$ nya, variabel yang nilai $\mathrm{p}$ nya $>0,05$ dikeluarkan dari model. Karena variabel umur dan komplikasi memiliki kategori lebih dari 2, maka harus dilakukan dummy variabel. Setelah proses pemodelan multivariat dilakukan, maka didapatlah model multivariat yang dapat dilihat pada Tabel 8 Model Multivariat berikut ini :

Tabel 8 Model Multivariat

\begin{tabular}{|c|c|c|c|c|c|c|c|}
\hline \multirow{2}{*}{ Model } & \multicolumn{2}{|c|}{ Unstandardized Coefficients } & \multirow{2}{*}{ 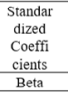 } & \multirow{2}{*}{$\mathrm{t}$} & \multirow{2}{*}{ Sig. } & \multirow{2}{*}{ R Square } & \multirow{2}{*}{$\begin{array}{l}\text { Anova } \\
\text { (Sig.) }\end{array}$} \\
\hline & B & Sid. Error & & & & & \\
\hline (Constant) & $590,681.6$ & $340,578.3$ & & 1.734 & 0.084 & \multirow{6}{*}{0,280} & \multirow{6}{*}{0,0005} \\
\hline $\begin{array}{l}\text { Tipe } \\
\text { Penatalaksanaan }\end{array}$ & $2,010,116.6$ & $378,783.2$ & 0.325 & 5.307 & 0.0005 & & \\
\hline Log Lama Sakit & $406,623.8$ & $160,084.8$ & 0.156 & 2.540 & 0.012 & & \\
\hline Komplikasil & $458,240.6$ & $387,864.3$ & 0.086 & 1.181 & 0.239 & & \\
\hline Komplikasi2 & $1,019,509.2$ & $278,812.6$ & 0.311 & 3.657 & 0.0005 & & \\
\hline Komplikasi3 & $1,824,201.0$ & $305,819.9$ & 0.491 & 5.965 & 0.0005 & & \\
\hline
\end{tabular}

Variabel independen yang masuk kedalam model regresi adalah Tipe Penatalaksanaan, Lama sakit dan Komplikasi yang dialami. Pada Tabel 8 Model Akhir juga memperlihatkan nilai koefisien determinasi ( $R$ Square) yaitu 0,280 artinya bahwa model regresi yang ada atau seluruh variabel independen dapat menjelaskan $28 \%$ variasi variabel dependen atau biaya langsung medis penderita rawat jalan diabetes mellitus tipe 2 di RSUD dr. Abdul Aziz Singkawang tahun 2013. Selain itu, pada nilai ANOVA menunjukkan nilai $\mathrm{p}=0,0005(<0,05)$, yang berar- 
ti pada alpha $5 \%$ dapat dinyatakan bahwa model regresi yang ada cocok atau fit dengan data yang ada. Pada nilai koefisien B diperoleh persamaan regresinya, yaitu :

\begin{tabular}{|cl|}
\hline $\begin{array}{c}\text { Biaya } \\
\text { Langsung } \\
\text { Medis }\end{array}$ & $\begin{array}{l}590,682+2,010,117 \text { (Tipe Penatalaksanaan) }+406,624 \\
\text { (Log Lama Sakit) }+458,241 \text { (Komplikasi1) }+1,019,509 \\
\text { (Komplikasi2) }+1,824,201 \text { (Komplikasi3) }\end{array}$ \\
\hline
\end{tabular}

Dari persamaan regresi diatas, variabel yang paling besar pengaruhnya terhadap perbedaan rata-rata biaya langsung medis penderita rawat jalan diabetes mellitus tipe 2 di RSUD dr. Abdul Aziz Singkawang tahun 2013 adalah variabel tipe penatalaksanaan yaitu penderita dengan terapi insulin saja dan kombinasi dengan $\mathrm{OHO}$.

\section{Pembahasan}

Rata-rata biaya langsung medis penderita rawat jalan diabetes mellitus tipe 2 dalam satu tahun

Hasil temuan biaya langsung medis secara agregat selama setahun pada penelitian ini hampir sama dengan hasil Soewondo P, dkk (2013), dari penelitian Andayani TM, dkk tahun 2004 pada 100 penderita diabetes mellitus tipe 2 di Rumah Sakit Kodya Yogyakarta (Rumah Sakit tipe B) dengan rata-rata biaya per bulan sebesar US\$ 19,97 dan penelitian Andayani TM, dkk lainnya tahun 2005 di Rumah Sakit dr. Sardjito Yogyakarta (Rumah Sakit Tipe A) dengan rata-rata biaya per bulan Rp. 208.500,- (US\$ 21).

Komposisi terbesar biaya langsung medis penderita rawat jalan diabetes mellitus tipe 2 yang ditemukan adalah biaya untuk obat-obatan yang mencapai $75,65 \%$ dari total biaya. Besaran biaya untuk obat-obatan pada penelitian ini, tidak jauh berbeda dengan data PT. ASKES pada tahun 2012. Biaya rawat jalan penderita diabetes mellitus tipe 2 di Indonesia yaitu sebesar 71,07\% untuk pengobatan dan 28,93\% untuk selain pengobatan (Widiyani R, 2013).

Selain itu, rata-rata biaya untuk obat-obatan diabetes mellitus berupa terapi $\mathrm{OHO}$ dan insulin pada penelitian ini sebesar $47,3 \%$ dari total biaya rawat jalan penderita diabetes mellitus tipe 2 dalam setahun. Angka ini jauh lebih tinggi bila dibandingkan dengan data pada penelitian ADA tahun 2012 yang hanya sebesar 25,8\% dari total biaya rawat jalan dan menjadi $16,6 \%$ dari total biaya langsung medis (biaya rawat jalan dan inap).

Sedangkan proporsi biaya untuk pengobatan komplikasi dan komorbiditas pada penelitian ini yang sebesar $28,34 \%$ dari total biaya rawat jalan, masih lebih tinggi bila dibandingkan dengan data pada penelitian ADA tahun 2012 yang sebesar 26,3\% dan menjadi $16,9 \%$ dari total biaya langsung medis (biaya rawat jalan dan inap). Bila dilihat dari data komponen biaya langsung medis pada penelitian ADA tahun 2012. Rendahnya proporsi biaya obat-obatan pada penderita diabetes mellitus tipe 2 di Amerika Serikat, disebabkan karena selain biaya obatobatan terdapat biaya ke dokter praktik, pelayanan gawat darurat dan ambulans, rawat jalan ke rumah sakit, rumah sehat (home health) untuk pelayanan promotif dan preventif serta pelayanan podiatry yaitu pemeriksaan gigi (dentists) dan pemeriksaan mata (optometrists).

Perbedaan rata-rata biaya langsung medis untuk penderita rawat jalan diabetes mellitus tipe 2 dalam setahun pada penderita laki-laki dan perempuan.

Hasil analisis menunjukkan bahwa biaya langsung medis pada penderita laki-laki lebih tinggi dibandingkan dengan perempuan.

Hasil penelitian ini sesuai dengan penelitian sebelumnya oleh Wang W et al, (2010), bahwa pada analisis multivariat variabel jenis kelamin memiliki pengaruh signifikan terhadap direct medical cost (DMC) dengan nilai $\mathrm{p}=0,039$, dimana biaya langsung medis pada penderita laki-laki sebesar CNY 8,410 lebih tinggi dibandingkan dengan perempuan yaitu sebesar CNY 7,581.

Pada penderita laki-laki terdapat 53,3\% yang mendapat terapi insulin saja dan kombinasi dengan $\mathrm{OHO}$ dibandingkan dengan $46,7 \%$ pada penderita perempuan. Selain itu, pada penderita laki-laki terdapat $84,4 \%$ yang mengalami komplikasi dibandingkan dengan penderita perempuan yang $79,8 \%$ saja. Jadi, faktor terapi insulin saja dan kombinasi dengan $\mathrm{OHO}$ serta kondisi komplikasi yang dialami mempengaruhi besarnya biaya langsung medis pada penderita laki-laki.

Faktor terapi insulin pada penderita laki-laki sesuai dengan pendapat Eliza B Geer dan Wei Shen (2010), laki-laki umumnya lebih resisten terhadap insulin daripada wanita, dimana pria memiliki lebih banyak lemak visceral dan hati daripada wanita, sedangkan wanita memiliki lebih banyak lemak subkutaneus yang berhubungan dengan peningkatan sensitifitas terhadap insulin.

Laki-laki cenderung lebih tinggi kemungkinan untuk mengalami komplikasi sudah sesuai dengan penelitian Litwak et al (2013). Dari 17.506 sampel yang mengalami komplikasi makrovaskuler sebanyak $54,1 \%$ adalah penderita laki-laki dan bahkan di negara Asia Selatan mencapai $64,3 \%$. Selain itu, dari 35.033 yang mengalami komplikasi mikrovaskuler 52,9\% adalah penderita laki-laki dan di negara Asia Selatan mencapai 61,1\%). Hasil analisis regresi menyimpulkan bahwa perempuan memiliki korelasi negatif dengan komplikasi makrovaskuler dengan tingkat signifikansi $<0,0001$ dengan nilai OR 0,88 (95\% $\mathrm{CI}=0,83-0,92)$.

Oleh sebab itu, pada penelitian ini biaya langsung 
medis pada penderita laki-laki cenderung lebih tinggi dibandingkan dengan perempuan.

Perbedaan rata-rata biaya langsung medis untuk penderita rawat jalan diabetes mellitus tipe 2 dalam setahun pada setiap kelompok umur penderita.

Hasil analisis menunjukkan bahwa biaya langsung medis dalam setahun, meningkat seiring meningkatnya kelompok umur penderita.

Hasil ini sesuai dengan penelitian ADA tentang biaya langsung medis penderita diabetes mellitus tahun 2007 di Amerika Serikat, dimana biaya untuk rawat jalan pada kelompok umur < 45 tahun US\$ 2.128 dari biaya total sebesar US\$ 3.808, lalu meningkat menjadi US\$ 2.600 (biaya total US\$5.094) pada kelompok umur $45 \mathrm{~s} / \mathrm{d} 64$ tahun dan kembali meningkat pada kelompok umur $\geq 65$ tahun menjadi US\$ 3.542 (biaya total US\$ 9.713).

Pada kelompok umur $<40$ tahun rata-rata lama sakit lebih singkat yaitu 3,25 tahun dibandingkan dengan kelompok umur $40 \mathrm{~s} / \mathrm{d} 59$ tahun yang 6,02 tahun dan $\geq 60$ sebesar 6,96 tahun. Hasil uji statistik (ANOVA) memperlihatkan nilai $\mathrm{p}=0,035$ (signifikan). Selain itu, terdapat 7,9\% pada kelompok umur $40 \mathrm{~s} / \mathrm{d} 59$ tahun dan $7,2 \%$ kelompok umur $\geq 60$ tahun mendapat terapi insulin saja dan kombinasi dengan $\mathrm{OHO}$ namun tidak ada yang mendapat terapi insulin saja dan kombinasi dengan $\mathrm{OHO}$ pada kelompok umur $<40$ tahun. Hal ini terjadi karena seiring bertambahnya umur penderita, sel-sel beta tidak mampu mengimbangi peningkatan kebutuhan akan insulin, maka kadar glukosa akan meningkat dan kebutuhan akan insulin juga meningkat.

Terdapat hanya 50\% yang mengalami komplikasi pada kelompok umur < 40 tahun, dibandingkan dengan 78,7\% pada kelompok umur 40 s/d 59 tahun dan $89,9 \%$ pada kelompok umur $\geq 60$ tahun. Hal ini sesuai dengan penelitian Litwak et al (2013) yang menyatakan bahwa terdapat korelasi positif antara umur dengan kejadian komplikasi makrovaskuler pada penderita diabetes mellitus tipe 2 dengan nilai signifikansi $\mathrm{p}<0,0001$ dengan nilai OR 1,05 (95\% CI = 1,05 - 1,06). Jadi, peningkatan umur penderita menyebabkan perbedaan lama sakit, terapi insulin saja dan kombinasi dengan $\mathrm{OHO}$ serta kondisi komplikasi yang dialami yang akhirnya mempengaruhi besarnya biaya langsung medis.

Perbedaan rata-rata biaya langsung medis untuk penderita rawat jalan diabetes mellitus tipe 2 dalam setahun pada setiap tipe penatalaksanaan.

Hasil analisis menunjukkan bahwa penderita yang mendapat terapi insulin saja dan kombinasi dengan $\mathrm{OHO}$ pada penelitian ini lebih tinggi dibandingkan dengan penggunaan insulin pada diabetes mellitus tipe 2 di In- donesia yang tergolong rendah dengan persentase penggunaan kombinasi $\mathrm{OHO}$ dan insulin sebesar 2,1\% dan persentase insulin intensif (insulin basal ditambah insulin post prandial) sebesar 4,6\% (IDF, 2012). Rendahnya penggunaan insulin disebabkan oleh beberapa faktor yaitu terdapatnya hambatan dalam memulai terapi insulin seperti resistensi psikologis, perubahan gaya hidup, perubahan fisik / mental dan masalah finansial.

Hasil analisis menunjukkan bahwa rata-rata biaya langsung medis penderita yang mendapat terapi insulin saja dan kombinasi dengan OHO hampir dua kali lipat lebih tinggi dibandingkan dengan penderita yang menggunakan obat berkhasiat hipoglikemik (OHO).

Hasil ini mengkonfirmasi penelitian sebelumnya oleh Henriksson F. et al (2000) di Swedia, bahwa pada penderita diabetes mellitus yang hanya mendapat intervensi diet tanpa obat rata-rata biaya langsung medis selama setahun adalah 15,312 SEK, lalu yang menggunakan obat oral anti diabetic saja sebesar 19,421 SEK, sedangkan penderita dengan terapi insulin dan kombinasi dengan obat oral anti diabetic biaya langsung medis meningkat cukup tinggi menjadi 40,042 SEK.

Pada penelitian lain oleh Koster I. et al (2006) di Jerman, biaya langsung medis pada penderita diabetes mellitus yang mendapat terapi insulin saja atau insulin dan obat oral anti diabetic memiliki rasio biaya sebesar masing-masing 3,4 dan 3,1 dibandingkan dengan kelompok kontrol. Sedangkan penderita diabetes mellitus yang mendapatkan terapi obat oral anti diabetic saja dan intervensi dengan diet dan olah raga memiliki rasio biaya 1,4 dibandingkan dengan kelompok kontrol.

Masih terdapat penelitian lain, yaitu oleh Wang W et al, (2010), menyatakan bahwa terapi insulin memiliki pengaruh yang signifikan pada biaya langsung medis penderita rawat jalan diabetes mellitus di Rumah Sakit di Cina dengan tingkat signifikansi kurang dari 1 persen $(p$ $<0,001$ ), dimana biaya langsung medis untuk penderita dengan terapi insulin sebesar CNY 11,047 dan yang tidak menggunakan terapi insulin hanya sebesar CNY 6,389.

Perbedaan rata-rata biaya langsung medis untuk penderita rawat jalan diabetes mellitus tipe 2 dalam setahun pada setiap penambahan satu tahun lama sakit. Rata-rata lama sakit penderita diabetes mellitus tipe 2 pada pendelitian ini lebih rendah dibandingkan dengan penelitian oleh Soewondo, $\mathrm{P}, \mathrm{dkk}(2008)$ dengan rata-rata lama sakit 8,61 tahun dengan standar deviasi 5,97 tahun. Selain itu, penelitian oleh Litwak et al(2013) rata-rata lama sakit penderita diabetes mellitus tipe 2 pada seluruh sampel adalah 8 tahun dengan standar deviasi 6,2 tahun. Namun, pada sebagian sampel yaitu di Cina dan Asia Sela- 
tan hampir sama dengan penelitian ini yaitu masing-masing 6,3 tahun $(S D \pm 6,3)$ dan 6,4 tahun ( $S D \pm 4,7$ ).

Hasil analisis menunjukkan setiap penambahan tahun lama sakit biaya langsung medis juga akan bertambah atau meningkat.

Hasil penelitian ini sudah sejalan dengan penelitian oleh Henriksson F. et al (2000), dimana makin lama sakit penderita diabetes mellitus tipe 2, maka biaya langsung medis makin meningkat. Pada penderita dengan lama sakit $<5$ tahun rata-rata biaya langsung medis setahun sebesar 20,977 SEK, antara 5 s/d 10 tahun sebesar 22,059 SEK dan > 10 tahun sebesar 31,409 SEK. Demikian juga dengan penelitian oleh Wang $\mathrm{W}$ et al, (2010), hubungan antara lama sakit dengan rata-rata biaya langsung medis selama setahun memiliki tingkat signifikansi kurang dari 1 persen $(\mathrm{p}<0,001)$. Pada penderita dengan lama sakit $\leq 5$ tahun biayanya sebesar CNY 6,416 sedangkan dengan lama sakit > 5 tahun sebesar CNY 8,869.

Penelitian Bahia LR et al (2011), total biaya yang dikeluarkan (biaya langsung dan biaya tidak langsung) selama setahun pada setiap penderita diabetes mellitus rawat jalan di Brazil signifikan dipengaruhi oleh lama sakit dengan tingkat signifikansi kurang dari 1 persen $(\mathrm{p}$ $<0,01)$, dimana lama sakit $\leq 10$ tahun rata-rata total biaya selama setahun sebesar US\$1,971, meningkat menjadi US\$ 2,173 dengan lama sakit $10 \mathrm{~s} / \mathrm{d} 19$ tahun dan kembali meningkat menjadi US\$ 2,544 pada penderita dengan lama sakit $\geq 20$ tahun.

Perbedaan rata-rata biaya langsung medis untuk penderita rawat jalan diabetes mellitus tipe 2 dalam setahun pada setiap jenis komplikasi yang dialami.

Hasil analisis menyatakan bahwa terdapat perbedaan yang signifikan rata-rata biaya langsung medis penderita rawat jalan diabetes mellitus tipe 2 dalam setahun pada setiap jenis komplikasi yang dialami.

Hasil penelitian ini, mengkonfirmasi penelitian sebelumnya, bahwa komplikasi yang dialami penderita berpengaruh terhadap biaya langsung medis. Penelitian Henriksson F. et al (2000), misalnya, menyatakan bahwa penderita yang tidak mengalami komplikasi biayanya sebesar 16,307 SEK, penderita dengan komplikasi mikrovaskuler biayanya sebesar 15,952 SEK, penderita dengan komplikasi makrovaskuler sebesar 29,518 SEK dan komplikasi keduanya menjadi sebesar 50,128 SEK. Selanjutnya Wang W et al, (2010), menyatakan bahwa hubungan antara komplikasi dengan rata-rata biaya langsung medis selama setahun memiliki tingkat signifikansi kurang dari 1 persen $(\mathrm{p}<0,001)$, dimana penderita yang tidak mengalami komplikasi biayanya sebesar CNY 5,372 dan yang mengalami komplikasi sebesar CNY 10,320.
Demikian juga penelitian oleh Bahia LR et al (2011), total biaya yang dikeluarkan selama setahun pada setiap penderita diabetes mellitus rawat jalan di Brazil signifikan dipengaruhi oleh komplikasi yang dialami dengan tingkat signifikansi kurang dari 1 persen $(\mathrm{p}<0,01)$, dimana pada penderita dengan komplikasi mikrovaskuler biayanya sebesar US\$2,062, penderita dengan komplikasi makrovaskuler meningkat menjadi US\$ 2,517 dan dengan komplikasi keduanya (mikro dan makrovaskuler) meningkat lagi menjadi US\$ 3,199.

Di Indonesia, penelitian oleh Andayani TM dkk, (2010) yang dilakukan di RS dr. Sardjito, Yogyakarta, dinyatakan bahwa penderita yang tidak mengalami komplikasi biaya langsung medisnya untuk 6 bulan sebesar US\$ 381,11 , meningkat menjadi US\$ 389,56 pada penderita dengan komplikasi mikrovasukuler, selanjutnya meningkat menjadi US\$ 431,66 pada penderita dengan komplikasi makrovaskuler dan pada penderita dengan komplikasi keduanya meningkat kembali menjadi US\$ 433,48. Penelitian lain oleh Soewondo P, (2013), penderita diabetes mellitus tipe 2 yang mengalami komplikasi mikro dan makrovaskuler total biaya pengobatan meningkat hingga $130 \%$ dibandingkan dengan penderita tanpa komplikasi.

Perbedaan rata-rata biaya langsung medis untuk penderita rawat jalan diabetes mellitus tipe 2 dalam setahun antara yang mengikuti dan tidak mengikuti Prolanis.

Hasil analisis memperlihatkan bahwa rata-rata biaya langsung medis penderita yang mengikuti Prolanis lebih tinggi dibandingkan dengan yang tidak mengikuti Prolanis.

Hasil penelitian ini berbeda dengan salah satu tujuan dilaksanakannya Prolanis bagi penderita diabetes mellitus tipe 2, yaitu agar biaya pelayanan kesehatan pada peserta menjadi efektif dan efisien. Walaupun tujuan akhirnya adalah untuk mencapai kualitas hidup yang optimal bagi penderita dengan mencegah timbulnya komplikasi penyakit.

Biaya obat-obatan menjadi penyebab utama.Rata-rata biaya obat pada penderita yang mengikuti Prolanis sebesar Rp. 1,931,399 lebih tinggi dari penderita yang tidak mengikuti Prolanis yaitu sebesar Rp. 1,755,372 dengan selisih sebesar Rp. 176,027. Sedangkan rata-rata biaya selain obat untuk penderita yang mengikuti Prolanis sebesar Rp. 547,798 lebih rendah dibandingkan dengan rata-rata biaya selain obat pada penderita yang tidak mengikuti Prolanis yaitu sebesar Rp. 616,078 dengan selisih sebesar Rp. 68,280.

Biaya obat-obatan yang tinggi pada penderita yang 
mengikuti prolanis lebih terlihat lagi saat dibandingkan dengan kondisi komplikasi yang dialami penderita. Penderita yang tidak mengalami komplikasi, mengalami komplikasi mikrovaskuler dan komplikasi keduanya rata-rata biaya obat-obatan selalu lebih tinggi pada penderita Prolanis. Hanya pada penderita dengan komplikasi makrovaskuler saja rata-rata biaya obat-obatan lebih tinggi pada penderita yang tidak mengikuti Prolanis (Grafik 1).

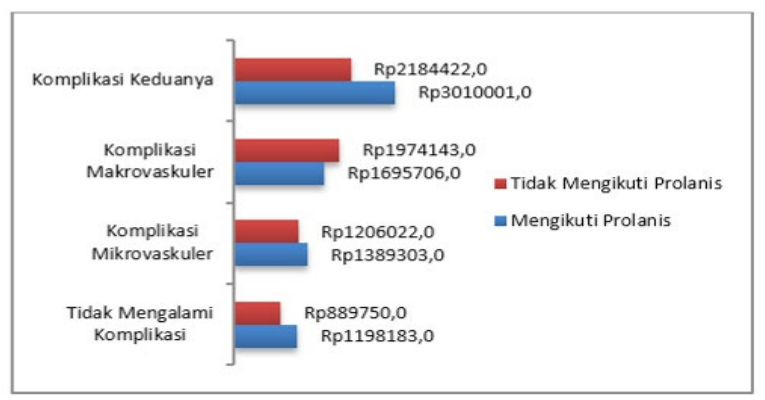

Grafik 1. Rata-rata biaya obat-obatan pada kondisi komplikasi yang dialami

Obat kombinasi yang ada pada DPHO dan dijadikan dasar untuk terapi penderita rawat jalan diabetes mellitus tipe 2 di RSUD dr. Abdul Aziz Singkawang memiliki 4 sub kelas terapi dengan mekanisme kerja yang berbeda, yaitu Sulfonil Urea (SU), Biguanid, Alpha Glukosida Inhibitor (AGI) dan Tiazolidinedion (TZD).Pada seluruh sampel penelitian ini, terdapat terapi OHO kombinasi menggunakan 4 jenis obatdengan mekanisme kerja berbeda sebanyak 53 penderita $(26,5 \%)$ dan penderita dengan terapi kombinasi $\mathrm{OHO}$ dengan 3 jenis obat dengan mekanisme kerja berbeda sebanyak 93 penderita (46,5\%). Sedangkan pada penderita yang mengikuti Prolanis terdapat 28,4\% penderita dengan terapi OHOkombinasi menggunakan 4 jenis obat dengan mekanisme kerja berbeda lebih tinggi dibandingkan dengan yang tidak mengikuti Prolanis sebesar 25,4\%(Tabel 9).

Tabel 9. Terapi Kombinasi OHO pada Penderita Diabetes Mellitus Tipe 2

\begin{tabular}{|c|c|c|c|c|c|c|c|}
\hline \multirow{3}{*}{ No } & \multirow{3}{*}{ Kombinasi Obat } & \multirow{2}{*}{\multicolumn{2}{|c|}{ Seluruh Sampel }} & \multicolumn{4}{|c|}{ Keikutsertaan dalam Prolanis } \\
\hline & & & & \multicolumn{2}{|c|}{$\begin{array}{l}\text { Mengikuti } \\
\text { Prolanis }\end{array}$} & \multicolumn{2}{|c|}{$\begin{array}{c}\text { Tidak } \\
\text { Mengikuti } \\
\text { Prolanis }\end{array}$} \\
\hline & & Jumlah & $\%$ & Jumlah & $\%$ & Jumlah & $\%$ \\
\hline 1. & $\begin{array}{l}\text { Kombinasi } 0 \text { (insulin saja) } \\
\text { s/d } 2 \text { jenis OHO }\end{array}$ & 54 & 27,0 & 19 & 25,7 & 35 & 27,8 \\
\hline 2. & $\begin{array}{l}\text { Kombinasi dengan } 3 \text { jenis } \\
\text { OHO atau dengan Insulin }\end{array}$ & 93 & 46,5 & 34 & 45,9 & 59 & 46,8 \\
\hline 3. & $\begin{array}{l}\text { Kombinasi dengan } 4 \\
\text { jenis OHO atau dengan } \\
\text { Insulin }\end{array}$ & 53 & 26,5 & 21 & 28,4 & 32 & 25,4 \\
\hline & Total & 200 & 100 & 74 & 100 & 126 & 100 \\
\hline
\end{tabular}

Berdasarkan Algoritma Pengelolaan Diabetes Mellitus Tipe 2 terapi dengan OHO kombinasi maksimal adalah menggunakan kombinasi 3 jenis obat dengan mekanisme kerja berbeda. Penggunaan kombinasi obat yang banyak ini berpengaruh terhadap biaya obat yang tinggi dan menyebabkan tingginya biaya untuk penderita yang mengikuti Prolanis.

Karena biaya langsung medis pada penelitian ini under-costing atau under-estimation yang disebabkan belum standarnya pelayanan rawat jalan diabetes mellitus tipe 2 di RSUD dr. Abdul Aziz Singkawang yang mengacu pada Konsensus Pengendalian dan Pencegahan Diabetes Mellitus Tipe 2 di Indonesia 2011. Biaya langsung medis pada penderita Prolanis yang lebih tinggi dibandingkan dengan yang tidak mengikuti Prolanis seharusnya tidak menjadi masalah. Asal biaya untuk obat-obatan, terutama obat diabetes mellitus (OHO dan insulin) serta biaya obat-obatan untuk mengatasi komplikasi dan komorbiditas semakin kecil proporsinya. Sebaliknya biaya untuk selain obatobatan, seperti untuk pemeriksaan berkala proporsinya harus semakin meningkat. Hal ini menunjukkan makin baiknya pelayanan yang diberikan pada penderita diabetes mellitus tipe 2 .

Berdasarkan data yang ada, Prolanis memberikan dampak positif bagi penderita diabetes mellitus tipe 2 . Dampak pertama adalah lebih rendahnya jumlah kunjungan ke Rumah Sakit. Pada penderita yang mengikuti Prolanis rata-rata kunjungan rawat jalan ke RSUD dr. Abdul Aziz tahun 2013 sebanyak 5,07 kali, sedangkan yang tidak mengikuti Prolanis lebih tinggi yaitu 6,29 kali. Walaupun kecil perbedaannya tentu hal ini akan memperkecil biaya selain obat. Hal ini disebabkan karena penderita yang mengikuti Prolanis dan dalam kondisi terkontrol/ stabil diikutsertakan dalam program rujuk balik ke pelayanan tingkat pertama baik ke puskesmas maupun dokter keluarga.

Sedangkan untuk tujuan meningkatkan kualitas hidup penderita dengan mencegah terjadinya komplikasi terlihat dari hasil analisis. Penderita yang mengikuti Prolanis dan mengalami komplikasi adalah 59 (79,7\%) dari 74 penderita sedangkan penderita yang tidak mengikuti Prolanis dan mengalami komplikasi adalah 105 (83,3\%) dari 126 penderita. Walaupun perbedaannya kecil, namun Prolanis berdampak untuk mengurangi kejadian komplikasi yang dialami oleh penderita diabetes mellitus tipe 2 .

\section{Kesimpulan dan Saran \\ Kesimpulan}

Berdasarkan hasil penelitian dapat dirumuskan beberapa simpulan sebagai berikut :

1. Rata-rata biaya langsung medis untuk setiap penderita rawat jalan diabetes mellitus tipe 2 di RSUD dr. Abdul Aziz Singkawang Tahun 2013 sebesar Rp. 2.406.325,-Sebagian besar dipergunakan untuk obat-obatan yang mencapai $75,65 \%$. Sedangkan biaya selain obat hanya 
24,35\% yang terdiri dari biaya pemeriksaan laboratorium dan biaya lainnya.

2. Tidak ada perbedaan yang bermakna rata-rata biaya langsung medis dalam setahun pada penderita laki-laki dan perempuan.

3. Tidak ada perbedaan yang bermakna rata-rata biaya langsung medis dalam setahun pada setiap kelompok umur penderita.

4. Ada perbedaan yang bermakna rata-rata biaya langsung medis dalam setahun pada setiap tipe penatalaksanaan.

5. Ada perbedaan yang bermakna rata-rata biaya langsung medis dalam setahun pada setiap penambahan satu tahun lama sakit.

6. Ada Perbedaan yang bermakna rata-rata biaya langsung medis dalam setahun pada setiap jenis komplikasi yang dialami.

7. Tidak ada perbedaan yang bermakna rata-rata biaya langsung medis dalam setahun antara yang mengikuti dan tidak mengikuti Prolanis.

8. Faktor yang paling dominan/besar pengaruhnya terhadap perbedaan rata-rata biaya langsung medis penderita rawat jalan diabetes mellitus tipe 2 adalah pada penderita dengan terapi insulin saja dan kombinasi dengan $\mathrm{OHO}$.

\section{Saran}

\section{Bagi Penderita}

Biaya langsung medis penderita rawat jalan diabetes mellitus tipe 2 sangat dipengaruhi oleh lama sakit, terapi insulin dan kombinasi insulin dengan obat berkhasiat hipoglikemik (OHO) dan komplikasi yang dialami. Variabel lama sakit, akan sulit untuk perbaiki oleh penderita. Faktor terapi insulin yang paling dominan pengaruhnya pada biaya langsung medis dapat diatasi dengan upaya memperbaiki pemakaian insulin oleh tubuh.

Upaya memperbaiki pemakaian insulin oleh tubuh adalah dengan olahraga dan latihan fisik. Selain itu, adanya komplikasi dan komorbiditas yang berpengaruh terhadap biaya langsung medis dapat dicegah dengan cara melakukan diet dan pengendalian berat badan, olahraga dan latihan fisik, minum obat berkhasiat hipoglikemik maupun terapi insulin secara teratur untuk mengendalikan kadar glukosa darah dan aktif mengikuti Program Pengelolaan Penyakit Kronis (PROLANIS).

\section{Bagi RSUD dr. Abdul Aziz Singkawang}

Proporsi biaya obat-obatan yang tinggi pada biaya langsung medis memperlihatkan ketergantungan yang tinggi penderita pada pengobatan. Hal ini disebabkan karena pelayanan rawat jalan pada penderita diabetes mellitus tipe 2 belum sesuai standar. Banyaknya penderita dengan terapi kombinasi $\mathrm{OHO}$ dengan $3-4$ jenis obat dengan mekanisme berbeda membuat biaya obat-obatan menjadi tinggi. Belum lagi ditambah dengan terapi untuk komplikasi dan komobiditas yang dialami penderita. Sebaliknya, biaya untuk pemantauan kesehatan penderita berupa pemeriksaan laboratorium dan pemeriksaan penunjang lainnya secara berkala belum optimal dilakukan. Upaya penerapan standar pelayanan bagi penderita rawat jalan diabetes mellitus tipe 2 dapat dilakukan di RSUD dr. Aziz Singkawang yang berpedoman pada Konsensus Pengelolaan dan Pencegahan Diabetes Melitus Tipe 2 di Indonesia Tahun 2011 dan panduan klinis Prolanis. Dengan penerapan standar pelayanan, proporsi biaya obat-obatan akan semakin kecil dan proporsi biaya selain obat-obatan dapat ditingkatkan. Ini berarti kualitas pelayanan pada penderita juga meningkat terutama penatalaksanaan terhadap komplikasi dan komorbiditas yang dialami penderita. Selain itu, edukasi terhadap penderita untuk mengontrol dan mengendalikan kadar glukosa darah dengan menerapkan pengaturan makan (diet) dan kegiatan jasmani perlu ditingkatkan.

\section{Bagi BPJS Kesehatan}

Diabetes mellitus tipe 2 adalah penyakit kronis sehingga perlu pengobatan yang lama. Selain itu, sebagian besar penderita mengalami komplikasi dan komorbiditas sehingga memerlukan biaya yang besar(high costs). Hasil penelitian memperlihatkan bahwa upaya untuk meningkatkan kualitas hidup penderita dan biaya pelayanan kesehatan yang efektif dan efisien melalui Prolanis belum optimal. Namun, Prolanis bila diterapkan sesuai standar, diharapkan dapat mencegah komplikasi dan komorbiditas pada penderita dengan melakukan deteksi dini dan mengontrol kadar gula darah penderita. Sedangkan penderita dengan komplikasi dan komorbiditas dilakukan penatalaksanaan secara komprehensif sehingga komplikasi dan komorbiditasnya tidak bertambah berat. Akhirnya dapat meningkatkan kualitas hidup penderita serta efisiensi biaya. Namun perlu waktu dan tidak bisa cepat terlihat hasilnya.

\section{Bagi Dinas Kesehatan Kota Singkawang}

1. Upaya Pengembangan Infrastruktur Pengendalian diabetes mellitus tipe 2 .

Sistem rujukan berjenjang dapat diatasi melalui revitalisasi puskesmas. Program revitalisasi puskesmas bertujuan mengembalikan puskesmas kepada fungsi utamanya. Program revitalisasi puskesmas terkait penyakit tidak menular adalah pengadaan sistem jejaring yang efektif dan efisien, peningkatan kuan- 
titas dan kualitas sumber daya manusia, penyediaan standar pelayanan minimum(SPM) yang komprehensif dan holistik, pengadaan alat kesehatan atau prasarana diagnostik dan pengobatan sesuai standar.

2. Upaya Peningkatan Kompetensi Tenaga Kesehatan. Selain infrastruktur kesehatan, kompetensi tenaga kesehatan juga perlu ditingkatkan. Dokter di FKTP harus mampu melakukan tatalaksana diabetes mellitus tanpa komplikasi. Dinas Kesehatan harus memaksimalkan program pelayanan terpadu penyakit kronis (PROLANIS) di puskesmas dan FKTP lain sebagai provider mitra BPJS Kesehatan. Program ini menempatkan dokter layanan di FKTP sebagai gatekeeper dengan prinsip layanan terkendali mutu dan biaya. Strategi promosi kesehatan dalam program itu adalah skrining faktor risiko. Pasien berisiko tinggi dikelola melalui kegiatan komunikasi, informasi dan edukasi (KIE), olahraga, gaya hidup sehat, serta konsultasi rutin ke dokter di FKTP. Penderita yang didiagnosis diabetes mellitus tipe 2 dikelola melalui program pencegahan sekunder dan tersier, yaitu program pengelolaan diabetes mellitus (PPDM).

\section{Daftar Pustaka}

American Diabetes Association (2004), Gestasional Diabetes Mellitus. Diabetes Care: Volume 27, 1 Januari 2004. American Diabetes Association (2007), Economic Costs of Diabetes in the U.S.in 2007, Diabetes CareVolume 31, 3 Maret 2008.

American Diabetes Association (2012), Economic Costs of Diabetes in the U.S.in 2012, Diabetes Care Publish Ahead of Print, published online March 6, 2013

Andayani TM et al (2010), Assessing The Impact Of Complications On The Direct Medical Costs Of Type 2 Diabetes Mellitus Outpatients, International Journal of Current Pharmaceutical Research, 4 Januari 2010

Ariawan I (1998), BesardanMetodeSampelpadaPenelitianKesehatan, Jurusan Biostatistik dan Kependudukan, Fakultas Kesehatan Masyarakat, Universitas Indonesia, Depok.

Bahia LR et al (2011), The Costs of Type 2 Diabetes Mellitus Outpatient Care in the BrazilianPublic Health System,
Value in Health S137-S140, Science Direct.

Eliza B Geer, Wei Shen., (2010), GenderDifferences in Insulin Resistance, Body Composition, and Energy,Supplemen1.,Gend Med. National Institute Of Health (NIH). Harnowo P A. (2012), DiabetesPenyakitMahal yang Tak Cukup Pengobatan Sekali, http://health.detik.com(Accessed 20Mei 2014)

Hastono S P. (2007), Analisis Data Kesehatan. Depok: Fakultas Kesehatan Masyarakat, Universitas Indonesia. Henriksson F. et al (2000), Direct medical cost patients with type 2 diabetes in Sweden. Journal of Internal Medicine. 248: 387-396.

IDF, (2011), IDF Diabetes Atlas, Fifth Edition, International Diabetes Federation.

IDF, (2012), Global Guidline For type 2 Diabetes.,Clinical GuidlinesTask Force, International Diabetes Federation, Belgium.

Kemenkes RI (2013), Riset Kesehatan Dasar.Jakarta: BadanPenelitian danPengembangan Kesehatan.

Kosma CM et al (1993), Economics, clinical, and humanistic outcomes. Dalam Arnold RJG. PharmacoeconomicsFrom Theory to Practice. Boca Raton: CRC Press, 2010. Koster I. et al (2006), The cost burden of diabetes mellitus: the evidence from German - the CoDIM Study. Article Diabetologi. 49: 1498-1504.

Litwak et al (2013), Prevalence of diabetes complications in people with type 2 diabetes mellitus and its association with baseline characteristics in the multinational A1chieve study, Diabetology\& Metabolic Syndrome, 5:57

Notoatmodjo S. (2010), MetodologiPenelitianKesehatan Jakarta: RinekaCipta.

Perkumpulan Endokrinologi Indonesia (2011), KonsensusPengelolaandanPencegahan Diabetes Mellitus tipe 2 di Indonesia. Jakarta: PERKENI.

Rascati K. (2009), Essential of Pharmacoeconomics. Philadelphia: Lippincott Williams \& Wilkins.

Soegondo, S., Soewondo, P., Subekti, I. (2009).Penatalaksanaandiabetes mellitus terpadu. Panduanpenatalaksanaan diabetes mellitus bagidokterdanedukator.Jakarta :BalaiPen- 
erbitan FKUI.

Soewondo P, $\mathrm{dkk}(2010)$, Outcomes on control and complications of type 2 diabetic patients in Indonesia, The DiabCare Asia 2008 study

Soewondo P, dkk (2013), Challenges in diabetes management in Indonesia: a literature review Globalization and Health2013 9:63.

Soewondo P, (2013), HarapanBaruPenyandang Diabetes Mellitus pada Era JaminanKesehatanNasional 2014, PidatopadaPengukuhanSebagai Guru BesarllmuPenyakitDalamFKUI, DepartemenIlmuPenyakitDalamFakultasKedokteranUniversitas Indonesia/ RumahSakitCiptoMangunkusumo,Jakarta.
Wang W et al, (2010),Factors affecting costs and utilization of type 2 diabetes healthcare: a cross-sectional survey among 15 hospitals in urban China, BMC Health Services Research, 10:24.

Weber et al, (2007), Retrospective Study Self-Monitoring of Blood Glucose and Outcome in People with type 2 DiabetesA Health Economic Assessment,J Diabetes Sci Technol. Sep 2007; 1(5): 676-684.

Widiyani R, (2013), Cegah DM, PerkecilBiayaKesehatanHingga 30 Persen, http://health.kompas.com. (Accessed 20 Mei 2014)

Whiting David R et al, (2011), IDF Diabetes Atlas: Global estimates of the prevalence of diabetes for 2011 and 2030, diabetes research and clinical practice 94 (2011) 311 $-321$. 